INTERNATIONAL JOURNAL OF SYSTEMATIC BACTERIOLOGY

Vol. 17, No. 1 January 1967 pp. 53-55

Copyright 1966 by the Iowa State University Press

\title{
SEROLOGICAL VARIETIES OF SHIGELLA FLEXNERI SEROTYPE 5
}

\section{N. A. Khomenko}

Metchinikoff Institute of Vaccines and Sera Mos cow, USSR

SUMMARY. It is proposed that Shigella flexneri serotype 5 be divided into two subserotypes, $5 \mathrm{a}$ and $5 \mathrm{~b}$. The former (subtype $\mathrm{x}-$ ) is agglutinated in absorbed group-factor serum 3,4 and the latter (subtype $x+$ ) in absorbed group factor serum 7,8 .

According to the International Classification Schema of the genus Shigella, Shigella flexneri serotype 5 is not divided into subtypes. However two varieties of $\underline{S}$. flexneri type 5 which differ in their group antigens have been isolated in the USSR.

The 118 strains of $\underline{S}$. flexneri type 5 which are at our disposal have been divided into two serological subtypes. One subtype consists of 27 strains which are agglutinated in absorbed group-factor serum 7,8 (so-called subtype $x+$ ), and the remaining 91 strains which do not react with this serum, are agglutinated in serum 3,4 (subtype $x-$ ). These reactions are listed in the following table.

Table 1. The serological varieties of $\underline{S}$. flexneri type 5 (slide tests).

\begin{tabular}{cccccc}
\hline & \multicolumn{5}{c}{ Absorbed Serums } \\
\cline { 2 - 6 } $\begin{array}{l}\text { No. of } \\
\text { strains }\end{array}$ & $\begin{array}{c}\text { Type specific } \\
\mathrm{V}\end{array}$ & $\begin{array}{c}\text { Group } \\
\text { Factors }\end{array}$ & Subtypes \\
91 & ++++ & ++++ & - & - & $5(\mathrm{x}-)=5 \mathrm{a}$ \\
27 & ++++ & - & - & ++++ & $5(\mathrm{x}+)=5 \mathrm{~b}$
\end{tabular}

++++ indicates high degree of agglutination

- indicates absence of agglutination 
A part of our collection ( 96 strains) was examined by the agglutinin absorbtion cross reaction test (Khomenko 1962), and the presence of 2 serotypes was manifested.

Similar serological varieties of $\underline{S}$. flexneri type 5 were also isolated in China (Fang-Kang and Wang-Hwa-tun 1957).

Occasionally some of our cultures which reacted with absorbed serum 3, 4 lost this capacity and reacted with type serum $\mathrm{V}$ only, but after some time the group components were restored. On the contrary the loss of the group antigens in the strains of the other subtype $\left(x^{+}\right)$has never been observed by the author.

The isolation in the USSR of S. flexneri type 5 is of special interest, since in many other countries these organisms were never (or very rarely) found (Slopek and Metzger 1958; Vertenyi 1960; Petersen 1962; Istrati et al. 1965). This fact apparently explains the lack of attention to the taxonomy of

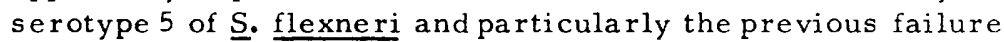
of recognizing the presence of subserotypes in serotype 5.

The data presented here seem to testify to the predominance of the serological subtype which reacts with the serum 3,4 (91 strains of 118). Therefore it seems to be expedient to supplement the International Schema of Classification of

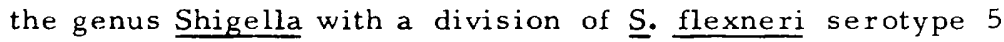
into two subtypes: $5 a$ and $5 b$.

\section{REFERENCES}

Ewing, W.H. and K.P. Carpenter. 1966. Recommended designations for the subserotypes of Shigella flexneri. Internatl. J. System. Bact. 16(2):145-149.

Fang Kang and Wang Hwa-tun. 1957. An etiological survey on bacillary dysentery in Peking, 1954-1955. Acta Microbiol. Sinica 5(I):179-182.

Istrati, G., T. Meitert and C. Ciufeco. 1965. Incidence des Shigella en Roumanie pendant periode 1953-1964. Arch. Roum. de Pathol. exp. et de microbiol., 244(4): 979-985.

Khomenko, N.A. 1962. A study of S. flexneri type 5 (P 119) is olated in USSR. J. Microbiol. Epidemiol. , Immunol. (Moscow), 10:96-101.

Petersen, K.F. 1962. Salmonella und Shigella. Befunde in Südbaden 1945-1961. Arch. für Hyg. u. Bacter., 146(6): 438-454. 
Slopek, St., and M. Metzger. 1958. Serological studies on Shigella strains isolated in Poland during 1953-1956. Schweiz. Zeitschr. Path. u. Bacter., 21 (I):32-53. Vertenyi, A. 1960. Distribution of Shigella flexneri serotypes in Hungary between 1945-1958. Acta Microbiol. Acad. Scien. Hung., VII(4):411-418. 